\title{
Association between the APOB Xbal and EcoRI polymorphisms and lipids in Chinese: a meta-analysis
}

Wei Gu', Mingduo Zhang ${ }^{2}$ and Shaojun Wen ${ }^{*}$

\begin{abstract}
Background: No previous meta-analysis was to report the association between the apolipoprotein B (APOB) Xbal and EcoRI polymorphisms and serum lipids in Chinese. We performed the study to investigate their potentially association.

Methods and Results: Studies in English and Chinese were found via a systematic search of Pubmed, Embase, CNKI and Wanfang databases. The dominant genetic model and random-effects model were used to pool data from individual studies. As a result, a total of 30 articles with 5611 subjects for Xbal and 2653 subjects for EcoRl were included in the current study. For the Xbal polymorphism, overall, subjects carrying X+ allele were significantly associated with higher TC,TG and LDL compared with X-X-genotype (Pvalue $=0.0006, \mathrm{OR}(95 \%)=-0.55(-0.86,-0.23)$; Pvalue $=0.0004$, OR $(95 \%)=-0.30(-0.47,-0.14) ;($ Pvalue $=0.05$, OR $(95 \%)=-0.23(-0.46,-0.00)$, respectively) . Similar results were observed in the subgroups of Han, healthy individuals (HT), coronary heart disease (CHD), cerebral infarction $(\mathrm{Cl})$, and cholelithiasis. For HDL, positive association between $\mathrm{X}+$ allele with Lower lipid value was found in $\mathrm{CHD}$ and $\mathrm{Cl}$ subgroups. For EcoRI polymorphism, overall, the $\mathrm{E}$ - allele carriers were found to be obviously linked with elevated $\mathrm{LDL}$ and lower $\mathrm{HDL}$ compared with $\mathrm{E}+\mathrm{E}+$ genotype (Pvalue $=0.02, \mathrm{OR}$ $(95 \%)=-0.27(-0.49,-0.05)$; Pvalue $=0.01$, OR $(95 \%)=0.17(0.03,0.30)$, respectively). TC was significantly high in subjects carrying E- allele in the subgroup of hyperlipidemia. No evidence of publication bias was observed.
\end{abstract}

Conclusions: The two genetic variants of APOB may be associated with serum lipids in Chinese.

Keywords: Apolipoprotein B or APOB, Chinese, Lipid, Polymorphism

\section{Introduction}

Many epidemiological studies have reported that metabolic disorders in serum lipids are considerable risk factors for premature coronary artery disease and atherosclerosis [1]. Serum lipids are multifactorial that emphasize the contribution of genetic as well as environmental factors. Genetically determined variation has been shown to have a close relationship with the metabolism abnormality of lipids and the pathogenesis of atherosclerosis [2, 3]. Although no convincing gene has been found to be of the importance for lipids, the obvious candidate genes are still necessary for a better understanding of lipid metabolism.

\footnotetext{
*Correspondence: anzhenwensj@sina.com

'Department of Hypertension Research, Beijing Anzhen Hospital, Capital Medical University and Beijing Institute of Heart Lung and Blood Vessel Diseases, 2 Anzhen Road, Beijing 100029, People's Republic of China Full list of author information is available at the end of the article
}

Apolipoprotein B (APOB) is an important protein component in contribution to intermediate density lipoprotein, the formation of very low density lipoprotein, low density lipoprotein particle, and is related to the clearance of LDL in serum. Beside these, it mediates cellular uptake of cholesterol and is the ligand that binds to the LDL receptor [4]. The gene coding for APOB has been cloned and is located on the short arm of chromosome 2 (q23q24). Many variants of the APOB gene has been found to be directly linked with lipid levels. In our study, among these variants, we paid particular attention to the most investigated XbaI (rs693) in exon 26 and EcoRI (rs1042031) in exon 29 single nucleotide polymorphisms in the APOB gene.

A meta-analysis by Boekholdt et al. [5] ten years ago had showed the relationship between the XbaI and EcoRI polymorphisms and lipids in Caucasian subjects. However, no meta-analysis about their association has concentrated 
on Chinese up to now. The ethnic difference in genetic background between Caucasian and Chinese may result in different findings. Moreover, the results of many published papers for the two polymorphisms in Chinese were inconclusive. Some of them showed strong associations between the $\mathrm{XbaI}$ and EcoRI polymorphisms in the APOB gene and serum lipids, whereas others had null association. Therefore, we performed a systematic meta-analysis of all eligible studies investigating the APOB XbaI and EcoRI polymorphisms and their association with serum lipids in Chinese.

\section{Methods}

\section{Literature search and selection criteria}

To identify the studies evaluating the relationship between the APOB XbaI and EcoRI polymorphisms and lipid profile in Chinese, a computerized literature search of PubMed, EMBASE, Wanfang and CNKI databases was carried out, applying the following keywords: 'apolipoprotein B or APOB', 'polymorphism', 'lipid', 'Chinese or China or Taiwanese or Taiwan' (up to September 1, 2015). The articles in English and Chinese would be included. References of the relevant articles were also examined. If multiple articles used the same data, only the more detailed one was selected. The included studies should be accordance with the later criteria: (i) studies evaluating the association of the APOB XbaI and EcoRI polymorphisms with lipids in Chinese, (ii) At least one of the lipid phenotypes was measured: total cholesterol (TC), triglyceride (TG), low density lipoprotein(LDL), and high density lipoprotein(HDL), (iii) Sufficient data involving genotype frequency as well as mean and standard deviation (SD) of lipids, (iv) If the article was a retrospective casecontrol study, each population (case/control groups) was treated as a single study and genotype frequency among control populations must be tested for Hardy-Weinberg equilibrium (HWE). If the genotype frequency was not supplied or calculated, the writers of these papers would be contacted by emails.

\section{Data extraction}

Two of the authors extracted the information from each study independently. Inconsistencies were discussed between the authors to reach an agreement. For each study, the following information would be collected: first author, year, ethnicity, resident region, detection method, sample size, character of participants, and lipid phenotypes of each study.

\section{Statistical analysis}

In our study, standardized mean difference (SMD) with their $95 \%$ CIs were used to measure the strength of the association of the APOB XbaI and EcoRI polymorphisms with lipids. For the two polymorphisms, we tested the dominant genetic model (X-X- vs. $\mathrm{X}+\mathrm{X}-/ \mathrm{X}+\mathrm{X}+, \mathrm{E}+\mathrm{E}+$ vs. $E+E-/ E-E-)$, because the low frequency of homozygosity for the mutant alleles would yield a large number of studies with zero cell counts, leading to the unreliable estimates, and the $\mathrm{X}+\mathrm{X}-/ \mathrm{X}+\mathrm{X}+$ and $\mathrm{E}+\mathrm{E}-/ \mathrm{E}-\mathrm{E}-$ genotypes in most studies were combined into one group. The random-effects model was used to assess the pooled estimates and the significance of the pooled estimates was determined using a Z-test. Heterogeneity among studies was assessed by the $\mathrm{X}^{2}$-based $\mathrm{Q}$-statistic test and considered significant for $P<0.10$ [6]. Subsequently based on racial ground, subgroup analysis was undertaken for Han and non-Han minority in Chinese. In addition, subgroup analysis for the XbaI polymorphism was also planned for healthy individuals (HT), coronary heart disease (CHD), cerebral infarction(CI), hyperlipidemia and cholelithiasis. Subgroup analysis for the EcoRI polymorphism was performed for healthy individuals $(\mathrm{HT})$, coronary heart disease (CHD) and hyperlipidemia. Each subgroup had at least three independent studies. Sensitivity analysis was carried out by removing a single study each time in order to find out whether any single study could bias the overall estimate. Sensitivity analysis were used to detect the cause of heterogeneity when the between-study heterogeneity would exist. Finally, we evaluated publication bias by funnel diagram. The funnel diagram asymmetry, suggesting publication bias, was precisely assessed by Egger's linear regression test and Begg's rank correlation test $[7,8]$ we re-calculated HWE using a web program (http://ihg.gsf.de/cgi-bin/hw/hwal.pl). All data were analyzed with Review Manager 5.0 (Oxford, UK) and STATA 12.0 (Stata Corp., TX, USA). All $P$ values reported were two-sided, and a significance level of less than 0.05 was considered statistically significant.

\section{Results}

Inclusion and characteristics of studies

As a beginning analysis, 77 relevant articles were found after literature search and selection. Among these selected studies, 43 articles were removed because their data were overlapping or duplicated. One paper [9] was deleted due to meta-analysis and two $[10,11]$ were excluded due to lack of the available information. For the EcoRI polymorphism, the data from 3 studies [12-14] was excluded as they deviated from HWE. Finally, the remaining 30 articles [13-42] with 5611 subjects for XbaI and 2653 subjects for EcoRI were included in this meta-analysis. Among them, Fan et al. [18] was an unpublished theses from the dissertation database, that is, an open sub-database shared by Wanfang and CNKI. 14 articles [14-16, 20, 22, 24, 27, 28, 30-34, 36] provided the available data on case and controls, which would be respectively handled as the separate two studies for each analysis. For all eligible studies, HWE had been recounted 
and had to be obeyed. The characteristics of the included studies were showed in Table 1.

In our study, based on the available genotype and allele frequency, we observed that, the $\mathrm{X}+$ allele frequency of $\mathrm{XbaI}$ was $7.0 \%$ in the whole population, and the Eallele frequency of EcoRI was $8.0 \%$, which both obviously had a lower frequency of the mutant allele than the Caucasian population.

\section{Association of the Xbal polymorphism with various lipids} The results of the relationship between the APOB XbaI ploymorphism and lipids in Chinese were shown in Table 2. In this analysis of TC, 5468 subjects (37 studies) were included. Overall, we observed that, TC was significantly high in subjects carrying $\mathrm{X}+$ allele compared with $\mathrm{X}$-X- genotype $\left(P_{\text {value }}=0.0006\right.$, OR $\left.(95 \%)=-0.55(-0.86,-0.23)\right)$. Similar findings were seen in the subgroups of $\operatorname{Han}\left(P_{\text {value }}=0.001\right.$, OR $(95 \%)=-0.59(-0.94,-0.24)), \mathrm{CI} \quad\left(P_{\text {value }}=0.007\right.$, OR $(95 \%)=-0.85(-1.46,-0.24))$ and cholelithiasis $\left(P_{\text {value }}=\right.$ 0.004 , OR $(95 \%)=-0.54(-0.91,-0.18))$. However, no positive association was obtained in the subgroups of non-Han minorities, HT, CHD, and hyperlipidemia. For the TG analysis, 5425 subjects (37 studies) were collected. In the whole population, $\mathrm{X}+$ allele carriers were found to be obviously associated with higher TG value compared with X-X- genotype $\left(P_{\text {value }}=0.0004\right.$, OR $\left.(95 \%)=-0.30(-0.47,-0.14)\right)$. Similar results were observed in the subgroups of Han $\left(P_{\text {value }}=0.0009\right.$, OR $\left.(95 \%)=-0.32(-0.50,-0.13)\right)$, HT

Table 1 Main characteristics of the included studies in the meta-analysis

\begin{tabular}{|c|c|c|c|c|c|c|c|}
\hline First author,year & Ethnicity & Region & Sample size & SNPS & Character of subjects & Method & Lipid profile \\
\hline Bai, [15]2008 & Han & Ningxia & 165 & EcoRl & $\mathrm{CA} / \mathrm{HT}$ & PCR-RFLP & TC,TG,LDL,HDL \\
\hline Chai, [16] 1996 & Han & Shanghai & 82 & Xbal & $\mathrm{Cl} / \mathrm{HT}$ & PCR-RFLP & TC,TG,LDL,HDL \\
\hline Evans, [17] 1993 & Han & Shanxi & 143 & Xbal & $\mathrm{HT}$ & PCR-RFLP & $\mathrm{TG}, \mathrm{LDL}, \mathrm{HDL}$ \\
\hline Fan, [18] 2009 & Han & Fujian & 387 & Xbal & Hyperlipidemia & PCR-RFLP & TC,TG,LDL,HDL \\
\hline Guo, [19] 1996 & Han & Liaoning & 55 & Xbal & $\mathrm{Cl}$ & PCR-RFLP & TC,TG,LDL,HDL \\
\hline Han, [20] 2000 & Han & Shanghai & 631 & Xbal & Cholelithiasis/HT & PCR-RFLP & TC,TG,LDL,HDL \\
\hline $\mathrm{Hu},[21] 2008$ & Han & Guangxi & 150 & Xbal & PNS & PCR-RFLP & TC,TG,LDL,HDL \\
\hline Hu, [13] 2009 & Han & Guangxi & 200 & Xbal & HT & PCR-RFLP & TC,TG,LDL,HDL \\
\hline $\mathrm{Ji},[22] 2014$ & Han & Inner mongolian & 120 & EcoRl,Xbal & Cholelithiasis/HT & PCR-RFLP & TC,TG,LDL,HDL \\
\hline Li, [23] 1997 & Han & Tianjing & 71 & EcoRl,Xbal & $\mathrm{CHD}$ & PCR-RFLP & TC,TG,LDL,HDL \\
\hline Liu, [24] 2008 & Han & Hunan & 230 & EcoRl & $\mathrm{Cl} / \mathrm{HT}$ & PCR-RFLP & TC,TG,LDL,HDL \\
\hline Liu, [25] 2010 & Han & Shanghai & 186 & Xbal & Gastric cancer & PCR-RFLP & $\mathrm{TC}, \mathrm{LDL}$ \\
\hline Liu,[26] 2014 & Li/Han & Hainan & 351 & Xbal & HT & PCR-RFLP & TC,TG,LDL,HDL \\
\hline Ma, [27] 2012 & Yao & Guangdong & 500 & EcoRl,Xbal & Hyperlipidemia/HT & PCR-RFLP & TC,TG,LDL,HDL \\
\hline Pan, [28] 1995 & Han & Taiwan & 301 & EcoRl,Xbal & $\mathrm{CHD} / \mathrm{HT}$ & PCR-RFLP & TC,TG,LDL,HDL \\
\hline Saha, [29] 1992 & Han & Singapore & 196 & EcoRl,Xbal & $\mathrm{HT}$ & PCR-RFLP & TC,TG,LDL,HDL \\
\hline Tan, [30] 2003 & Han & Jiangsu & 211 & EcoRl,Xbal & Cholelithiasis/HT & PCR-RFLP & TC,TG,LDL,HDL \\
\hline Wang, [31] 1999 & Han & Beijing & 377 & Xbal & $\mathrm{Cl} / \mathrm{HT}$ & PCR-RFLP & TC,TG,LDL,HDL \\
\hline Wei, [32] 2001 & Han & Sichuan & 169 & Xbal & Cholelithiasis/HT & PCR-RFLP & TC,TG,LDL,HDL \\
\hline Xie, [33] 2010 & Han & Xinjiang & 300 & EcoRl,Xbal & Hyperlipidemia/HT & PCR-RFLP & TC,TG,LDL,HDL \\
\hline Yan, [34] 2003 & Han & Beijing & 257 & EcoRl & $\mathrm{CHD} / \mathrm{HT}$ & PCR-RFLP & TC,TG,LDL,HDL \\
\hline Yao, [14] 1999 & Han & Jiangsu & 141 & Xbal & $\mathrm{Cl} / \mathrm{HT}$ & PCR-RFLP & TC,TG,LDL,HDL \\
\hline Yao, [35] 2005 & Han & Xinjiang & 112 & EcoRl,Xbal & fatty liver & DNA chips & TC,TG,LDL,HDL \\
\hline Ye, [36] 1995 & Han & Beijing & 203 & Xbal & $\mathrm{CHD} / \mathrm{HT}$ & PCR-RFLP & $\mathrm{TC}, \mathrm{TG}, \mathrm{LDL}, \mathrm{HDL}$ \\
\hline Ye, [37] 2003 & Han & Beijing & 88 & Xbal & Hyperlipidemia & PCR-RFLP & TC,TG,LDL \\
\hline Zhang, [39] 2009 & Han & Hunan & 130 & Xbal & $\mathrm{Cl}$ & PCR-RFLP & TC,TG,LDL,HDL \\
\hline Zhang,[38] 2010 & Han & Xinjiang & 154 & EcoRl & $\mathrm{CHD}$ & PCR-RFLP & TC,TG,LDL,HDL \\
\hline Zhang, [40] 2015 & Han & Beijing & 82 & EcoRl,Xbal & Hyperlipidemia & PCR-RFLP & $\mathrm{TC}, \mathrm{TG}, \mathrm{LDL}, \mathrm{HDL}$ \\
\hline Zhao, [41] 1997 & Han & Beijing & 117 & Xbal & $\mathrm{Cl}$ & PCR-RFLP & TC,TG,LDL,HDL \\
\hline Zhu, [42] 2001 & Han & Beijing & 308 & Xbal & HT & PCR-RFLP & TC,TG,LDL,HDL \\
\hline
\end{tabular}

CA carotid atherosclerosis, $H T$ healthy individuals, $C l$ cerebral infarction, PNS primary nephrotic syndrome, CHD coronary heart disease, $P C R$ - $R F L P$ polymerase chain reaction-restriction fragment length polymorphism, $T C$ total cholesterol, $T G$ triglyceride, $L D L$ low density lipoprotein, $H D L$ high density lipoprotein 
Table 2 Overall and subgroup associations of the APOB Xbal polymorphism and lipids

\begin{tabular}{|c|c|c|c|c|c|c|c|}
\hline Lipids & Overall or subgroups & Studies & Subjects & OR (95 \%) & $P_{\text {value }}$ & $P_{\text {heterogenity }}$ & $\mathrm{P}_{\mathrm{e}}$ \\
\hline \multirow[t]{8}{*}{ TC } & Overall & 37 & 5468 & $-0.55[-0.86,-0.23]$ & 0.0006 & $<0.01$ & 0.08 \\
\hline & Han & 34 & 4812 & $-0.59[-0.94,-0.24]$ & 0.001 & $<0.01$ & \\
\hline & Non-Han minorities & 3 & 651 & $-0.25[-0.61,0.10]$ & 0.16 & 0.08 & \\
\hline & $\mathrm{HT}$ & 16 & 2708 & $-0.61[-1.3,0.07]$ & 0.08 & $<0.01$ & \\
\hline & $\mathrm{CHD}$ & 3 & 322 & $0.02[-0.37,0.42]$ & 0.90 & 0.71 & \\
\hline & $\mathrm{Cl}$ & 6 & 577 & $-0.85[-1.46,-0.24]$ & 0.007 & $<0.01$ & \\
\hline & Hyperlipidemia & 5 & 957 & $-0.24[-0.71,0.22]$ & 0.31 & $<0.01$ & \\
\hline & Cholelithiasis & 4 & 456 & $-0.54[-0.91,-0.18]$ & 0.004 & 0.11 & \\
\hline \multirow[t]{8}{*}{ TG } & Overall & 37 & 5425 & $-0.30[-0.47,-0.14]$ & 0.0004 & $<0.01$ & 0.25 \\
\hline & Han & 34 & 4774 & $-0.32[-0.50,-0.13]$ & 0.0009 & $<0.01$ & \\
\hline & Non-Han minorities & 3 & 651 & $-0.19[-0.41,0.02]$ & 0.08 & 0.98 & \\
\hline & $\mathrm{HT}$ & 17 & 2851 & $-0.31[-0.62,0.00]$ & 0.05 & $<0.01$ & \\
\hline & $\mathrm{CHD}$ & 3 & 322 & $-0.53[-0.93,-0.13]$ & 0.009 & 0.41 & \\
\hline & $\mathrm{Cl}$ & 6 & 577 & $-0.50[-1.02,0.02]$ & 0.06 & 0.0001 & \\
\hline & Hyperlipidemia & 5 & 957 & $-0.29[-0.62,0.04]$ & 0.09 & 0.01 & \\
\hline & Cholelithiasis & 4 & 456 & $-0.11[-0.34,0.12]$ & 0.36 & 0.86 & \\
\hline \multirow[t]{8}{*}{ LDL } & Overall & 38 & 5611 & $-0.23[-0.46,-0.00]$ & 0.05 & $<0.01$ & 0.80 \\
\hline & Han & 35 & 4960 & $-0.23[-0.49,0.03]$ & 0.09 & $<0.01$ & \\
\hline & Non-Han minorities & 3 & 651 & $-0.26[-0.47,-0.04]$ & 0.02 & 0.5 & \\
\hline & $\mathrm{HT}$ & 17 & 2851 & $-0.21[-0.60,0.18]$ & 0.29 & $<0.01$ & \\
\hline & $\mathrm{CHD}$ & 3 & 322 & $0.15[-0.25,0.54]$ & 0.47 & 0.6 & \\
\hline & $\mathrm{Cl}$ & 6 & 577 & $-0.52[-1.08,0.05]$ & 0.07 & $<0.01$ & \\
\hline & Hyperlipidemia & 5 & 957 & $0.15[-0.47,0.78]$ & 0.63 & $<0.01$ & \\
\hline & Cholelithiasis & 4 & 456 & $-0.4[-0.64,-0.17]$ & 0.0007 & 0.46 & \\
\hline \multirow[t]{8}{*}{$\mathrm{HDL}$} & Overall & 36 & 5337 & $0.17[-0.08,0.41]$ & 0.18 & $<0.01$ & 0.86 \\
\hline & Han & 33 & 4686 & $0.15[-0.12,0.43]$ & 0.27 & $<0.01$ & \\
\hline & Non-Han minorities & 3 & 651 & $0.24[0.01,0.47]$ & 0.04 & 0.33 & \\
\hline & $\mathrm{HT}$ & 17 & 2851 & $0.11[-0.43,0.64]$ & 0.07 & $<0.01$ & \\
\hline & $\mathrm{CHD}$ & 3 & 322 & $0.50[0.11,0.90]$ & 0.01 & 0.78 & \\
\hline & $\mathrm{Cl}$ & 6 & 577 & $0.43[0.13,0.74]$ & 0.005 & 0.11 & \\
\hline & Hyperlipidemia & 4 & 869 & $0.10[-0.08,0.27]$ & 0.27 & 0.97 & \\
\hline & Cholelithiasis & 4 & 456 & $-0.10[-0.33,0.13]$ & 0.40 & 0.78 & \\
\hline
\end{tabular}

TC total cholesterol, TG triglyceride, $L D L$ low density lipoprotein, $H D L$ high density lipoprotein, $H T$ healthy individuals, $C H D$ coronary heart disease, $\mathrm{Cl}$ cerebral infarction

$P_{\text {value: }}$ the significance of the pooled estimate (95\% confidence interval)

$P_{\text {heterogeneity: }}$ the $\mathrm{Q}$ statistic for heterogeneity

$\mathrm{P}_{\mathrm{e}}$ : Egger's statistic for publication bias

All results were calculated under the dominant genetic model $(X-X-v s . X+X-/ X+X+)$

$\left(P_{\text {value }}=0.05\right.$, OR $\left.(95 \%)=-0.31(-0.62,0.00)\right)$ and CHD $\left(P_{\text {value }}=0.009\right.$, OR $\left.(95 \%)=-0.53(-0.93,-0.13)\right)$. There was no evidence of correlation in the subgroup of non-Han minorities, CI, cholelithiasis and hyperlipidemia.

For LDL, 5611 subjects (38 studies) were collected. Overall, a marginally positive association between $\mathrm{X}+$ allele with higher lipid value was found $\left(P_{\text {value }}=0.05\right.$, OR $(95 \%)=-0.23(-0.46,-0.00)$, Fig. 1). In the subgroup analysis, we also observed the significant association in
non-Han minorities $\left(P_{\text {value }}=0.02\right.$, OR $(95 \%)=-0.26$ $(-0.47,-0.04))$ and cholelithiasis $\left(P_{\text {value }}=0.0007\right.$, OR $(95 \%)=-0.4(-0.64,-0.17))$. No statistically significant differences were found in the subgroups of Han, HT, CHD, $\mathrm{CI}$ and hyperlipidemia. Finally for HDL, 5337 subjects (36 studies) were analyzed. No significant association was observed in the overall and in the subgroups of Han, HT, hyperlipidemia and cholelithiasis. In the non-Han minorities, $\mathrm{CHD}$ and $\mathrm{CI}$ subgroups, subjects carrying $\mathrm{X}+$ allele 


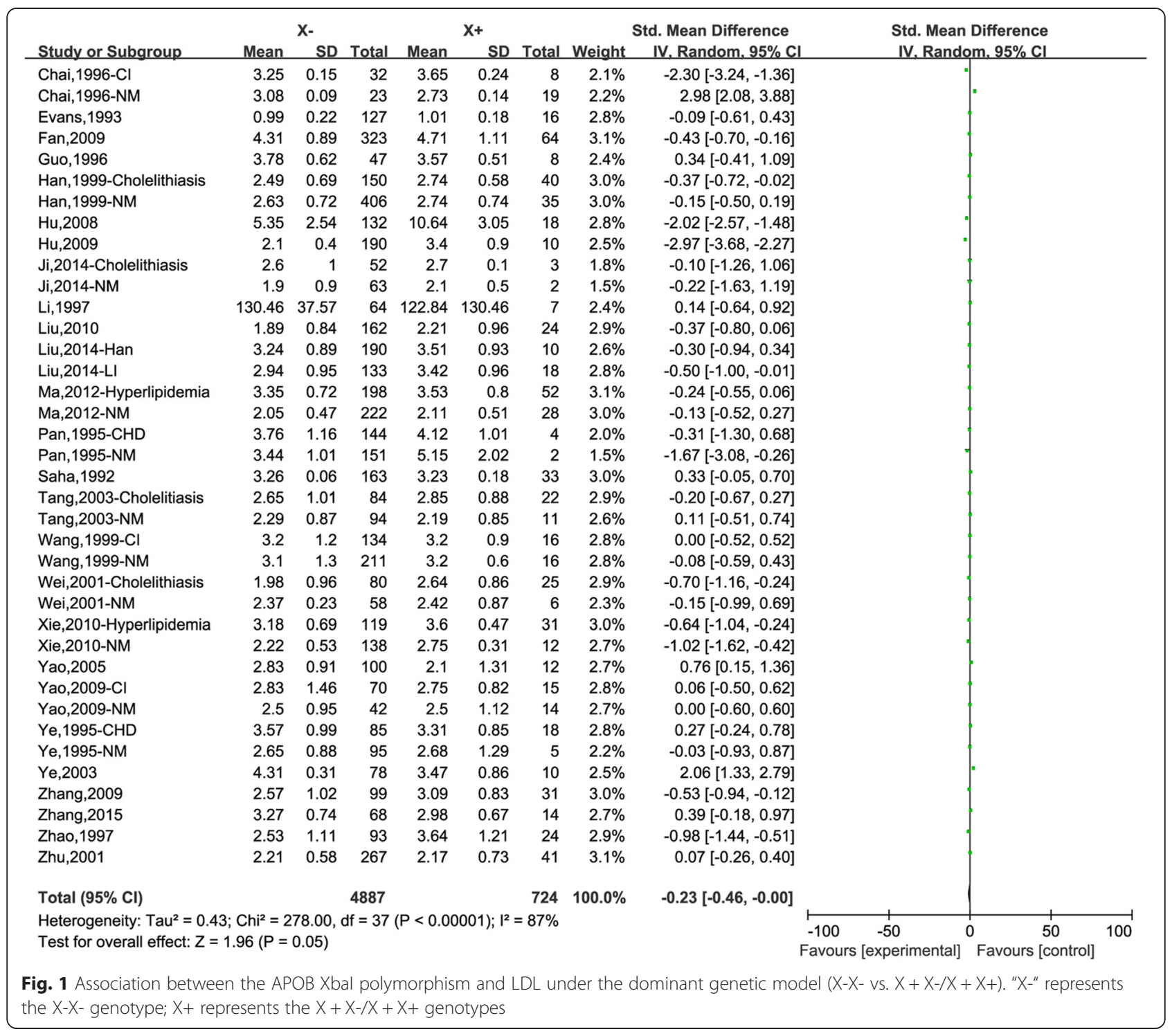

were associated with lower $\mathrm{HDL}$ value than $\mathrm{X}-\mathrm{X}-\left(P_{\text {value }}=\right.$ 0.04 , OR $(95 \%)=0.24(0.01,0.47) ; P_{\text {value }}=0.01$, OR $(95 \%)=0.50\left(0.11,0.90 ; P_{\text {value }}=0.005\right.$, OR $(95 \%)=0.43$ $(0.13,0.74)$, respectively $)$.

Association of the EcoRI polymorphism with various lipids The results of the relationship between the APOB EcoRI ploymorphism and lipids in Chinese were shown in Table 3. For TC, 2653 subjects (21 studies) were included. A significant association of the E- allele with higher TC was detected in the subgroup of hyperlipidemia $\left(P_{\text {value }}<0.01\right.$, OR $(95 \%)=-0.56(-0.78,-0.35))$. There was no difference in the whole population and in the subgroups of Han, HT and CHD. For TG, 2653 subjects (21studies) were assessed. We found no significant association between the EcoRI ploymorphism and TG in overall and even in the subgroup analysis. For LDL, 2653 subjects (21 studies) were found. Overall, subjects carrying the E- allele were found to be obviously linked with higher LDL compared with $\mathrm{E}+\mathrm{E}+$ genotype $\left(P_{\text {value }}=0.02\right.$, OR $(95 \%)=-0.27$ $(-0.49,-0.05)$, Fig. 2). Similar result was also shown in the subgroup of Han $\left(P_{\text {value }}=0.04\right.$, OR $(95 \%)=-0.28$ $(-0.53,-0.02))$. In the subgroups of HT, CHD and hyperlipidemia, no significant association was found. For the HDL analysis, 2653 subjects (21studies) were included. Overall, HDL was significantly low in subjects carrying the E- allele compared with $\mathrm{E}+\mathrm{E}+$ genotype $\left(P_{\text {value }}=0.01, \mathrm{OR}\right.$ $(95 \%)=0.17(0.03,0.30))$. However, in all the subgroups, there was no significant association.

\section{Sensitivity analysis}

In the sensitivity analysis, we deleted one study at a time and found whether there was a individual study affecting the pooled SMD and the between-study heterogeneity. 
Table 3 Overall and subgroup associations of the APOB EcoRI polymorphism and lipids

\begin{tabular}{|c|c|c|c|c|c|c|c|}
\hline Lipids & Overall or subgroups & Studies & Subjects & OR (95 \%) & $P_{\text {value }}$ & $P_{\text {heterogenity }}$ & $\mathrm{Pe}_{\mathrm{e}}$ \\
\hline \multirow[t]{5}{*}{$\mathrm{TC}$} & Overall & 21 & 2653 & $-0.28[-0.58,0.01]$ & 0.06 & $<0.01$ & 0.64 \\
\hline & Han & 19 & 2153 & $-0.27[-0.61,0.07]$ & 0.11 & $<0.01$ & \\
\hline & HT & 9 & 1142 & $-0.19[-0.89,0.52]$ & 0.61 & $<0.01$ & \\
\hline & $\mathrm{CHD}$ & 4 & 529 & $-0.25[-0.56,0.05]$ & 0.1 & 0.29 & \\
\hline & Hyperlipidemia & 3 & 482 & $-0.56[-0.78,-0.35]$ & $<0.01$ & 0.45 & \\
\hline \multirow[t]{5}{*}{ TG } & Overall & 21 & 2653 & $-0.14[-0.32,0.03]$ & 0.11 & 0.003 & 0.62 \\
\hline & Han & 19 & 2153 & $-0.14[-0.34,0.07]$ & 0.19 & 0.001 & \\
\hline & HT & 9 & 1142 & $-0.01[-0.35,0.34]$ & 0.97 & 0.002 & \\
\hline & $\mathrm{CHD}$ & 4 & 529 & $-0.26[-0.55,0.04]$ & 0.09 & 0.33 & \\
\hline & Hyperlipidemia & 3 & 482 & $-0.15[-0.49,0.18]$ & 0.37 & 0.11 & \\
\hline \multirow[t]{5}{*}{ LDL } & Overall & 21 & 2653 & $-0.27[-0.49,-0.05]$ & 0.02 & $<0.01$ & 0.51 \\
\hline & Han & 19 & 2153 & $-0.28[-0.53,-0.02]$ & 0.04 & $<0.01$ & \\
\hline & $\mathrm{HT}$ & 9 & 1142 & $-0.26[-0.59,0.07]$ & 0.13 & 0.005 & \\
\hline & $\mathrm{CHD}$ & 4 & 529 & $-0.21[-0.73,0.31]$ & 0.43 & 0.01 & \\
\hline & Hyperlipidemia & 3 & 482 & $-0.36[-0.88,0.15]$ & 0.17 & 0.006 & \\
\hline \multirow[t]{5}{*}{$\mathrm{HDL}$} & Overall & 21 & 2653 & $0.17[0.03,0.30]$ & 0.01 & 0.2 & 0.44 \\
\hline & $\operatorname{Han}$ & 19 & 2153 & $0.13[-0.02,0.28]$ & 0.09 & 0.2 & \\
\hline & HT & 9 & 1142 & $0.13[-0.09,0.35]$ & 0.25 & 0.25 & \\
\hline & $\mathrm{CHD}$ & 4 & 529 & $0.24[-0.03,0.52]$ & 0.08 & 0.5 & \\
\hline & Hyperlipidemia & 3 & 482 & $-0.03[-0.44,0.38]$ & 0.89 & 0.04 & \\
\hline
\end{tabular}

TC total cholesterol, TG triglyceride, LDL low density lipoprotein, HDL high density lipoprotein, $H T$ healthy individuals, CHD coronary heart disease $P_{\text {value: }}$ the significance of the pooled estimate (95\% confidence interval)

Pheterogeneity: the Q statistic for heterogeneity

$P_{\mathrm{e}}$ : Egger's statistic for publication bias

All results were calculated under the dominant genetic model $(E+E+v s . E+E-/ E-E-)$

\begin{tabular}{|c|c|c|c|c|c|c|c|c|c|}
\hline \multirow[b]{2}{*}{ Study or Subgroup } & \multicolumn{3}{|c|}{ E+ } & \multicolumn{3}{|c|}{ E- } & \multicolumn{2}{|r|}{ Std. Mean Difference } & \multirow{2}{*}{$\begin{array}{l}\text { Std. Mean Difference } \\
\text { IV. Random. } 95 \% \mathrm{Cl}\end{array}$} \\
\hline & Mean & SD & Total & Mean & SD & Total & Weight & IV. Random. $95 \% \mathrm{Cl}$ & \\
\hline $\mathrm{Bai}, 2008-\mathrm{CA}$ & 3.42 & 0.59 & 80 & 4.17 & 0.56 & 17 & $5.1 \%$ & $-1.27[-1.83,-0.72]$ & \\
\hline Bai,2008-NM & 3.42 & 0.59 & 59 & 4.17 & 0.56 & 9 & $4.1 \%$ & $-1.26[-2.00,-0.53]$ & \\
\hline Ji,2014-Cholelithiasis & 2.6 & 1 & 49 & 2.5 & 0.4 & 6 & $3.6 \%$ & $0.10[-0.75,0.95]$ & \\
\hline Ji,2014-NM & 1.9 & 0.9 & 61 & 2.2 & 0.9 & 4 & $2.9 \%$ & $-0.33[-1.34,0.68]$ & \\
\hline Li,1997-CHD & 134.27 & 37.81 & 78 & 113.79 & 40.28 & 12 & $4.7 \%$ & $0.53[-0.08,1.15]$ & \\
\hline Li,1997-NM & 122.86 & 34.63 & 76 & 115.35 & 37.23 & 4 & $2.9 \%$ & $0.21[-0.79,1.22]$ & \\
\hline Liu,2008-Cl & 2.58 & 0.98 & 105 & 3.09 & 0.84 & 25 & $5.7 \%$ & $-0.53[-0.97,-0.09]$ & \\
\hline Liu,2008-NM & 2.22 & 0.65 & 91 & 2.26 & 0.71 & 9 & $4.3 \%$ & $-0.06[-0.75,0.62]$ & \\
\hline Ma,2012-Hyperlipidemia & 3.31 & 0.67 & 209 & 3.37 & 0.75 & 41 & $6.3 \%$ & $-0.09[-0.42,0.25]$ & \\
\hline Ma,2012-NM & 2.03 & 0.45 & 222 & 2.19 & 0.55 & 28 & $6.0 \%$ & $-0.35[-0.74,0.05]$ & \\
\hline Pan,1995-CHD & 3.15 & 1.19 & 135 & 3.83 & 1.03 & 13 & $4.9 \%$ & $-0.57[-1.15,-0.00]$ & \\
\hline Pan,1995-NM & 3.52 & 1.01 & 138 & 3 & 1.32 & 15 & $5.2 \%$ & $0.50[-0.04,1.03]$ & \\
\hline Saha,1992 & 3.3 & 0.07 & 135 & 3.3 & 0.2 & 21 & $5.6 \%$ & $0.00[-0.46,0.46]$ & \\
\hline Tang,2003 & 2.77 & 0.89 & 88 & 2.32 & 1.01 & 18 & $5.3 \%$ & $0.49[-0.02,1.00]$ & \\
\hline Xie,2010-Hyperlipidemia & 3.07 & 0.66 & 94 & 3.59 & 0.56 & 56 & $6.3 \%$ & $-0.83[-1.17,-0.48]$ & \\
\hline Xie,2010-NM & 2.21 & 0.54 & 131 & 2.62 & 0.32 & 19 & $5.4 \%$ & $-0.79[-1.28,-0.30]$ & \\
\hline Yan,2003-CHD & 3.32 & 0.96 & 120 & 4.11 & 2.08 & 17 & $5.3 \%$ & $-0.68[-1.20,-0.17]$ & \\
\hline Yan,2003-NM & 2.89 & 0.79 & 108 & 3.08 & 0.55 & 12 & $4.8 \%$ & $-0.24[-0.84,0.35]$ & \\
\hline Yao,2005 & 2.86 & 0.98 & 111 & 2.15 & 0.5 & 1 & $1.1 \%$ & $0.72[-1.25,2.69]$ & \\
\hline Zhang,2010 & 2.4 & 0.9 & 137 & 2.46 & 0.93 & 17 & $5.3 \%$ & $-0.07[-0.57,0.44]$ & \\
\hline Zhang,2015 & 3.2 & 0.76 & 65 & 3.3 & 0.62 & 17 & $5.2 \%$ & $-0.13[-0.67,0.40]$ & \\
\hline Total $(95 \% \mathrm{Cl})$ & & & 2292 & & & 361 & $100.0 \%$ & $-0.27[-0.49,-0.05]$ & \\
\hline \multicolumn{7}{|c|}{$\begin{array}{l}\text { Heterogeneity: } \mathrm{Tau}^{2}=0.18 ; \mathrm{Chi}^{2}=67.89, \mathrm{df}=20(P<0.00001) ; \mathrm{I}^{2}=71 \% \\
\text { Test for overall effect: } Z=2.38(\mathrm{P}=0.02)\end{array}$} & & & $\begin{array}{ccccc} & 1 & 1 & 1 & 1 \\
-100 & -50 & 0 & 50 & 100 \\
\text { Favours [experimental] } & \text { Favours [control] }\end{array}$ \\
\hline
\end{tabular}


For the XbaI polymorphism, the removal of any single study did not obviously affect the heterogeneity and it still exist. However, the overall pooled SMD of LDL was apparently changed with the elimination in turn of eight studies (Chai- HT et al. [16], Guo et al. [19], Li et al. [23], Saha et al. [29], Yao et al. [35], Ye-CHD et al. [36], Ye et al. [37], and Zhang et al. [40]) (data not shown). For the EcoRI polymorphism, no individual study had an obvious influence on the between-study heterogeneity. After removing Saha et al. [29] for TC as well as Pan-HT et al. [28] and Saha et al. [29] for TG, the related overall pooled SMDs were changed (data not shown).

Finally, no significant publication bias was revealed under the dominant genetic model for XbaI $(P=0.08$ for TC, 0.25 for TG, 0.8 for LDL, 0.86 for HDL, Table 2) and for EcoRI $(P=0.64$ for TC, 0.62 for TG, 0.51 for LDL, 0.44 for HDL, Table 3).

\section{Discussion}

Some discrepancies could be caused by differences in ethnic background. Thus, we restricted the analysis to the Chinese population and performed a meta-analysis containing 30 articles with 5611 participants for XbaI and 2653 participants for EcoRI to more precisely understand the relationship between these polymorphisms and lipids in Chinese. So far this meta-analysis was the largest one investigating the association of these two polymorphisms in the AOPB gene with lipid level in Chinese. In the present study, we found that, $\mathrm{X}+$ allele of the $\mathrm{XbaI}$ polymorphism was significantly associated with higher TC,TG and LDL in all subject, and E- allele of the EcoRI polymorphism was obviously associated with higher LDL and lower HDL level. Our results involving XbaI were partially consistent with the findings of the previous meta [5]. The difference on the results about EcoRI may be due to the distinct genetic backgrounds of the included populations.

The Xbal polymorphism within the coding region of APOB mRNA is caused by a silent cytosine to thymine mutation in the third base of the threonine codon at residue 2488 in the mature APOB protein, and this site itself is of dubious functional significance. Nevertheless, this polymorphism may be a genetic indicator in linkage disequilibrium with other functional mutations in the APOB gene or a nearby-located gene [43, 44], which can affect the metabolism of serum lipids. Compared with $\mathrm{X}$-allele, $\mathrm{X}+$ allele carriers with higher LDL may be explained by differing clearance by the receptor-mediated pathway of LDL catabolism, and with higher TC/TG may be attributable to the production of a relatively receptorinactive APOB in the mutational group [45]. As a matter of fact, many studies have reported that, compared with the wild-type genotype, subjects with $\mathrm{X}+$ allele have apparently higher TC,TG, APOB and LDL levels $[5,46,47]$. The APOB EcoRI polymorphism in the coding sequence could result in an acidic basic amino acid substitution, which is non-conservative and has putative importance in $\mathrm{APOB}$ protein function [48]. E+ allele carriers in association with abnormal lipid parameters were observed in many studies compared with E- allele carriers [5, 13]. Taken together, APOB plays a critical role in the lipid transport. If the gene encoding APOB has mutational changes, APOB structure and function would be affected and finally lead to lipid metabolism disorder, such as increase of plasma ApoB and LDL, decrease of HDL, etc.

For the Han subgroup, owing to the largest ethnic in Chinese and most related studies included in our meta, the association between the XbaI and EcoRI polymorphism and lipids was largely consistent with the results in the whole population. Irregular results involving the non-Han minorities in Chinese was seemingly understandable in a complex genetic background and limited number of studies. Studies in a larger population based on a single minority are needed for a more clear observation. For the subgroups of HT, CHD, CI and cholelithiasis in the XbaI analysis, our finding were partially in accordance with the published four articles [5, 9, 49-50]. In addition, hyperlipidemia was diagnosed when one of the following four lipids (TC、LDL、HDL and TG ) was more than the normal serum level, and thus the statistical power of the single lipid (such as LDL) to detect differences may be limited due to the smaller involved sample size. For EcoRI, when considering the subgroup analysis of hyperlipidemia, the conclusion may be influenced and should be treated with caution, because sample size of the subgroup as well as study number were relatively small (482 and 3, respectively).

Future related studies in this area should consider several limitations in the present meta-analysis. Firstly, a significant heterogeneity was detected in the analysis, and its contributors may be population source, study design, etc. Secondly, due to the limited number of studies at this time, the subgroup analysis on non-Han minority populations (such as Yao) can not be well done. Thirdly, the analysis did not focus on the detailed functional research of the studied two polymorphisms. Finally, beside genetic influence, the relationship between $A P O B$ single nucleotide polymorphisms and lipid profile was also affected by many environmental factors that didn't be fully conducted in this study, which possibly confounded the results.

In conclusion, our meta-analysis showed significant association between the APOB XbaI polymorphism and lipids (TC, TG and LDL) in Chinese. Similar conclusions were observed in the subgroups of Han, HT, CHD, CI and cholelithiasis. For the AOPB EcoRI polymorphism, the Eallele carriers may be a genetic factor for higher LDL and lower HDL levels in Chinese. Additional studies with larger sample size should be conducted in Chinese to make clear the association of APOB SNPs with lipids. Studies investigating their detailed function were equally needed. 


\section{Abbreviations}

APOB: Apolipoprotein B; TC: Total cholesterol; TG: Triglycerides; LDL: Lowdensity lipoprotein; HDL: High-density lipoprotein; SD: Standard deviation; HWE: Hardy-Weinberg equilibrium; SMD: Standardized mean difference: HT: Healthy individuals; CHD: Coronary heart disease; Cl: Cerebral infarction; SNP: Single-nucleotide polymorphism; CA: Carotid atherosclerosis; PNS: Primary nephrotic syndrome.

\section{Competing interests}

The authors declare that they have no competing interests.

\section{Authors' contributions}

Conceived and designed the experiments: WG SW. Collected and analyzed the data: WG MZ SW. Wrote the manuscript: WG SW. Modified the manuscript: WG MZ SW. All authors read and approved the final manuscript.

\section{Acknowledgements}

We are very grateful and thank all the participants in this study. This study was financially supported by the Beijing Natural Science Foundation of China (Grant No. 7120001, 7133232) and the National High-tech Research and Development Projects (863) (No. 2008AA02Z441).

\section{Author details}

'Department of Hypertension Research, Beijing Anzhen Hospital, Capital Medical University and Beijing Institute of Heart Lung and Blood Vessel Diseases, 2 Anzhen Road, Beijing 100029, People's Republic of China. ${ }^{2}$ Department of cardiology, Beijing Anzhen Hospital, Capital Medical University, Beijing, People's Republic of China.

\section{Received: 3 September 2015 Accepted: 29 September 2015}

\section{Published online: 07 October 2015}

\section{References}

1. Burnett JR. Lipids, lipoproteins, atherosclerosis and cardiovascular disease. Clin Biochem Rev. 2004;25:2.

2. Heller DA, de Faire U, Pedersen NL, Dahlén G, McClearn GE. Genetic and environmental infuences on serum lipid levels in twins. N Engl J Med. 1993;328:1150-6

3. Pollin TI, Hsueh WC, Steinle NI, Snitker S, Shuldiner AR, Mitchell BD. A genome-wide scan of serum lipid levels in the Old Order Amish. Atherosclerosis. 2004;173:89-96.

4. Brown MS, Goldstein JL. A receptor-mediated pathway for cholesterol homeostasis. Science. 1986;232:34-47.

5. Boekholdt SM, Peters RJ, Fountoulaki K, Kastelein JJ, Sijbrands EJ. Molecular variation at the apolipoprotein $B$ gene locus in relation to lipids and cardiovascular disease: a systematic meta-analysis. Hum Genet. 2003;113:417-25

6. Lau J, loannidis JP, Schmid CH. Quantitative synthesis in systematic reviews. Ann Intern Med. 1997;127:820-6.

7. Begg CB, Mazumdar M. Operating characteristics of a rank correlation test for publication bias. Biometrics. 1994;50:1088-101.

8. Egger M, Davey Smith G, Schneider M, Minder C. Bias in meta-analysis detected by a simple, graphical test. BMJ. 1997;315:629-34.

9. Gong Y, Zhang L, Bie P, Wang H. Roles of ApoB-100 gene polymorphisms and the risks of gallstones and gallbladder cancer: a meta-analysis. PLoS ONE. 2013;8, e61456.

10. Saha N, Tong MC, Tay JS, Jeyaseelan K, Humphries SE. DNA polymorphisms of the apolipoprotein B gene in Chinese coronary artery disease patients. Clin Genet. 1992;42:164-70.

11. Su SG, Qin JR, Wei YL. Polymorphism of the apolipoprotein B gene in Zhuang nationality and Han nationality patients with coronary heart disease. Guangxi Yi Ke Da Xue Xue Bao. 2003;20:858-61.

12. Ye P, Chen BS, Wang SW. Polymorphisms of apolipoprotein B gene in relation to coronary heart disease in Chinese Han nationality. Chin Med J (Engl). 1994;107:30-5.

13. Hu P, Qin YH, Jing CX, Lu L, Hu B, Du PF. Effect of apolipoprotein B polymorphism on body mass index, serum protein and lipid profiles in children of Guangxi China. Ann Hum Biol. 2009;36:411-20.

14. Yao J, Wang Y, Wang ZZ, Li HJ, Ding XS, Cheng $\mathrm{H}$, et al. Analysis of apoB gene polymorphisms and plasma lipid levels in Chinese patients with atherosclerotic cerebral infraction. Zhongguo Shen Jing Mian Yi Xue Yu Shen Jing Bing Xue Za Zhi. 1999;6:20-2.

15. Bai YS, Zhou LP, Bai XD, Du QC. Study on the relationship between carotid atherosclerosis diseases and EcoRI \& Mspl polymorphisms of apolipoprotein B gene. Ningxia Yi Xue Yuan Xue Bao. 2008;30:157-60.

16. Chai YH, Qin Z, Qin ZJ, Yao JL, Su MF. Xbal polymorphisms of apolipoprotein B gene in relation to atherosclerotic cerebral infarction. Lin Chuang Shen Jing Bing Xue Za Zhi. 1996;9:70-3.

17. Evans AE, Zhang W, Moreel JF, Bard JM, Ricard S, Poirier O, et al. Polymorphisms of the apolipoprotein $B$ and $E$ genes and their relationship to plasma lipid variables in healthy Chinese men. Hum Genet. 1993;92:191-7.

18. Fan L. Correlation between $\mathrm{ApoB}$ and $\mathrm{ApoC}$ I gene polymorphisms and lipid-lowering efficacy of atorvastatin. MD. Thesis, Shenyang Yao Ke Da Xue. 2009.

19. Guo Y, Guo JJ, Wang FW, Wang AH. The relation between apolipoprotein B gene polymorphism and level of plasma lipids in patients with ICVD by polymerase chain reaction. Zhong Feng Yu Shen Jing Ji Bing Za Zhi. 1996:13:339-41.

20. Han T, Jiang Z, Suo G, Zhang S. Apolipoprotein B-100 gene Xba I polymorphism and cholesterol gallstone disease. Clin Genet. 2000;57:304-8.

21. Hu P, Qin TH, Jing CX, Lei FY, Li MF. Associations of the apoliproprotein $E$ and $\mathrm{B}$ gene polymorphisms with hyperlipidemia subsequenced to primary nephrotic syndrome. Zhongguo Xian Dai Yi Xue Za Zhi. 2008:18:3110-9.

22. Ji J, Liu Y, Yu YL, Shi JS. Relationship between apolipoprotein B gene Xba I and EcoR I polymorphisms and cholelithiasis. Zhonghua Xiao Hua Wai Ke Za Zhi. 2014;13:291-4.

23. Li FX, Huang TG, Li ZY, Zhou L, Liu SY. Relationship between apolipoprotein B gene polymorphisms and lipids metabolism and coronary heart disease. Shi Yong Xin Nao Fei Xue Guan Bing Za Zhi. 1997;5:1-5.

24. Liu BQ, Zhang L, Yang QD, Liu YH, Hu ZY, Xu HW, et al. The association of apolipoprotein $B$ gene polymorphism with cerebral infarction with positive family history and its effect on plasma lipid levels. Zhonghua Yi Xue Za Zhi. 2008:88:3332-6.

25. Liu FL, Lu WB, Niu WX. Xbal polymorphisms of apolipoprotein B gene: another risk factor of gallstone formation after radical gastrectomy. World J Gastroenterol. 2010;16:2549-53.

26. Liu YL, Zhang YB, Li Y, Ma RL, Cai WW, Lin-Jiang L, et al. Correlation between the Xba I polymorphism of apoB gene and serum lipid profiles in Li ethnic group. Asian Pac J Trop Med. 2014;7:63-6.

27. Ma ZZ, Huang WB, He FP, Zhang SB. Relationship between apolipoprotein B gene polymorphisms and lipid levels in Yao population of Yuebei area. Fen Zi Zhen Duan Yu Zhi Liao Za zhi. 2012;4:333-5.

28. Pan JP, Chiang AN, Tai JJ, Wang SP, Chang MS. Restriction fragment length polymorphisms of apolipoprotein B gene in Chinese population with coronary heart disease. Clin Chem. 1995;41:424-9.

29. Saha N, Tay JS, Humphries SE. Apolipoprotein B-gene DNA polymorphisms (Xbal and EcoRl), serum lipids, and apolipoproteins in healthy Chinese. Genet Epidemiol. 1992;9:1-10.

30. Tan YF, Yang S, Yu RB, Shen C, Ding WL, Zhou WM, et al. Relationship among the Xba I and EcoR I locus polymorphisms of apolipoprotein B gene, serum lipid metabolism and gallstone disease. Zhonghua Yi Xue Za Zhi. 2003;83:844-7.

31. Wang LY, Gu Y, Wu GX, Wang W, Liu J, Pan XD. The relation between polymorphisms of apolipoprotein B gene and atherosclerotic cerebral infarction. Zhonghua Yi Xue Za Zhi. 1999;79:603-6.

32. Wei JB, Lin QY, Chen NS, Zhang MY, Xiao LJ. Relationship among the Xba I locus polymorphisms of apolipoprotein B gene and gallstone disease. Zhonghua Yi Xue Yi Chuan Xue Za Zhi. 2001;18:66-7.

33. Xie YJ, Huang G, Chi YH. Association of EcoR I and Xba I polymorphisms of apolipoprotein B gene with dyslipidemia and lipid levels. Zhongguo Yi Shi Za Zhi. 2010;11:1452-6.

34. Yan SK, Li XL, Xue H, Song YH, Yang SD, Chen BS. Relationship between coronary heart disease and EcoRI \& Mspl polymorphisms of apolipoprotein B gene in Han nationality. Zhonghua Jian Yan Yi Xue Za Zhi. 2003;26:148-52.

35. Yao H, Xu FL, Zhu B, Zeng BF, Guo G, Zhang JR, et al. Study on the relationship between apolipoprotein B, Cll, E gene polymorphisms and lipids metabolism disorders of fatty liver patients. Xinjiang Yi Ke Da Xue Xue Bao. 2005;28:605-7.

36. Ye P, Chen B, Wang S. Association of polymorphisms of the apolipoprotein B gene with coronary heart disease in Han Chinese. Atherosclerosis. 1995;117:43-50. 
37. Ye $P$, Shang $Y$, Ding $X$. The influence of apolipoprotein $B$ and $E$ gene polymorphisms on the response to simvastatin therapy in patients with hyperlipidemia. Chin Med Sci J. 2003;18:9-13.

38. Zhang CJ, Mao Y, He BX. Relationship between coronary heart disease with diabetes and EcoRl polymorphism of apolipoprotein B gene in Uygur and Han nationality. Zhongguo Dong Mai Ying Hua Za Zhi. 2010;18:146-50.

39. Zhang L, Zeng Y, Ma M, Yang Q, Hu Z, Du X. Association study between C7673T polymorphism in apolipoprotein B gene and cerebral infarction with family history in a Chinese population. Neurol India. 2009;57:584-8.

40. Zhang PZ, Tian Y. Influence of apolipoprotein B gene polymorphisms over effect of exercise on blood lipid. Ti Yu Ke Xue. 2015;35:38-47.

41. Zhao RZ, Liu CJ, Shen BZ. The Xba1 polymorphism of the apolipoprotein B gene in Chinese atherosclerotic cerebral infarction patients. Beijing Yi Ke Da Xue Xue Bao. 1997;29:522-4.

42. Zhu WL, Feng NP, Wang Y, Ye GG. Gene polymorphism at apoB locus and the serum lipids profile in children. Wei Sheng Yan Jiu. 2011;30:280-2.

43. Huang LS, Ripps ME, Breslow JL. Molecular basis of five apolipoprotein B gene polymorphisms in non-coding regions. J Lipid Res. 1990;31:71-7.

44. Berg K, Powell LM, Wallis SC, Pease R, Knott TJ, Scott J. Genetic linkage between the antigenic group ( $\mathrm{Ag}$ ) variation and the apolipoprotein $\mathrm{B}$ gene: assignment of the Ag locus. Proc Natl Acad Sci U S A. 1986;83:7367-70.

45. Demant T, Houlston RS, Caslake MJ, Series JJ, Shepherd J, Packard CJ, et al. Catabolic rate of low density lipoprotein is influenced by variation in the apolipoprotein B gene. J Clin Invest. 1988;82:797-802.

46. Vrablik M, Ceska R, Horinek A. Major apolipoprotein B-100 mutations in lipoprotein metabolism and atherosclerosis. Physiol Res. 2001;50:337-43.

47. Aalto-Setälä K, Tikkanen MJ, Taskinen MR, Nieminen M, Holmberg P, Kontula $\mathrm{K}$. Xbal and c/g polymorphisms of the apolipoprotein $\mathrm{B}$ gene locus are associated with serum cholesterol and LDL-cholesterol levels in Finland. Atherosclerosis. 1988;74:47-54.

48. Bentzen J, Jørgensen T, Fenger M. The effect of six polymorphisms in the Apolipoprotein B gene on parameters of lipid metabolism in a Danish population. Clin Genet. 2002;61:126-34.

49. Cao Y, Fan X, Zhu W, Ni G, Qian Y, Han Y, et al. Association of C7673T polymorphism in apolipoprotein $B$ gene with ischemic stroke in the Chinese population: a meta-analysis. Int J Neurosci. 2015;20:1-9.

50. Li YY. ApoB gene Splns/Del, Xbal polymorphisms and myocardial infarction: a meta-analysis of 7169 participants. J Cardiovasc Med (Hagerstown). 2014;15:717-26.

\section{Submit your next manuscript to BioMed Central and take full advantage of:}

- Convenient online submission

- Thorough peer review

- No space constraints or color figure charges

- Immediate publication on acceptance

- Inclusion in PubMed, CAS, Scopus and Google Scholar

- Research which is freely available for redistribution 